\title{
Distribution, abundance and conservation status of Grauer's gorilla
}

\author{
Jefferson S. Hall, Kristin Saltonstall, Bila-Isia Inogwabini and llambu Omari
}

This report updates the distribution and provides abundance estimates for Grauer's gorilla Gorilla gorilla graueri across its 90,000-sq- $k m$ range. The authors divide the range of Grauer's gorilla into four regions within which they identify 11 populations and estimate a total of c. 16,900 individuals. Gorillas found in the Kahuzi-Biega lowland-Kasese region represent 86 per cent of the subspecies's total population. Further, approximately 67 per cent of known Grauer's gorillas inhabit Kahuzi-Biega, Maiko and Virunga National Parks. The eastern region of the Democratic Republic of Congo (formerly Zaire) has an extremely high human population growth rate indicating that deforestation and wildlife use trends will continue to increase. Thus, in spite of the encouraging results of surveys to identify populations and characterize abundance, no Grauer's gorilla population should be considered safe from extirpation.

\section{Introduction}

In 1959 John Emlen and George Schaller undertook the first range-wide assessment of eastern gorillas (Emlen and Schaller, 1960), including the first in-depth study of gorilla ecology (Schaller, 1963). Since this pioneering work, several surveys and censuses have been undertaken to determine the abundance of western gorillas Gorilla gorilla gorilla (e.g. Tutin and Fernandez, 1984; Carroll, 1988; Fay, 1989; Fay and Agnagna, 1992) and mountain gorillas G. g. beringei (e.g. Harcourt et al., 1981; Weber and Vedder, 1983). However, until 1990, few attempts were made to characterize populations of eastern lowland or Grauer's gorilla Gorilla gorilla graueri, partly due to the remoteness and inaccessibility of many of these populations.

In 1991, the Wildlife Conservation Society, in partnership with the Institut Zairois pour la Conservation de la Nature (now Institut Congolais pour la Conservation de la Nature), began a systematic effort to identify all populations of G. g. graueri and evaluate their status (Hall and Wathaut, 1992). This paper summarizes this effort and presents the first range- wide assessment of Grauer's gorilla to be based on field data since Emlen and Schaller (1960) first travelled through what is now eastern Democratic Republic of Congo (hereafter referred to as Congo). We identify and provide abundance estimates for all confirmed populations of this gorilla subspecies, and discuss prospects for survival of discrete populations in terms of threats.

\section{Distribution and abundance}

Using geographic and human barriers to movement, here we identify 11 populations within four general regions across the 90,000sq-km range of Grauer's gorilla (Figure 1). We estimate the total population of G. g. graueri to be approximately 16,900 gorillas (Table 1 ).

\section{Kahuzi-Biega National Park-Kasese region}

The entire Kahuzi-Biega National ParkKasese region $\left(1^{\circ} 8^{\prime}-2^{\circ} 29^{\prime} \mathrm{S}, 26^{\circ} 51^{\prime}-28^{\circ} 51^{\prime} \mathrm{E}\right)$ was once continuous forest (Figure 1). The habitat within this region spans an environmental gradient ranging from montane (Mt Kahuzi, 
$3308 \mathrm{~m}$ ) through mountain transition to lowland tropical forest (Kasese, $600 \mathrm{~m}$ ). An overview of the vegetation of the mountain sector was given by Steinhauer-Burkhart et al.

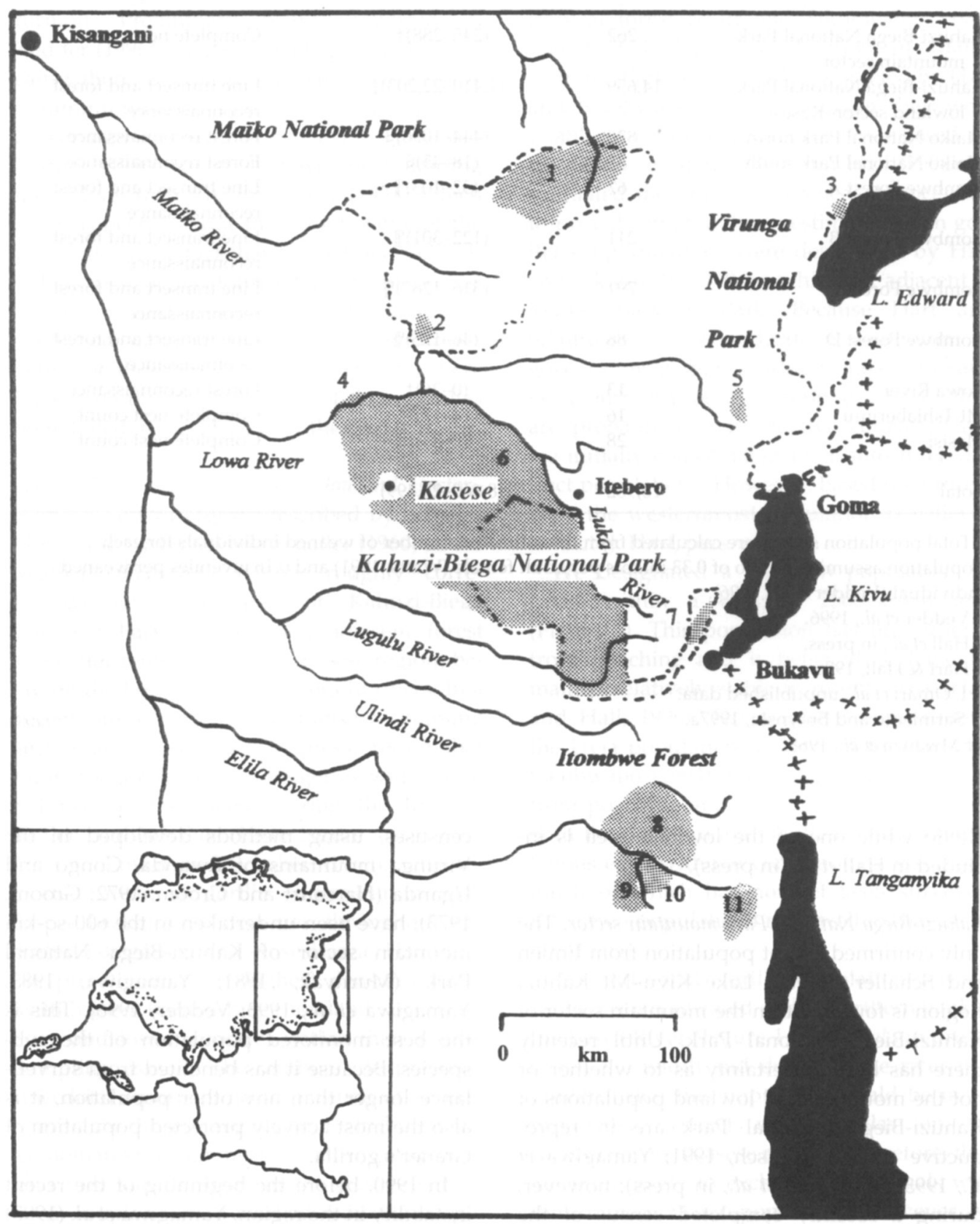

Figure 1. Distribution of Grauer's gorilla (Gorilla gorilla graueri) populations. 1, Maiko National Park, north; 2 , Maiko National Park, south; 3, Mt Tshiaberimu; 4, Lowa River; 5, Masisi; 6, Kahuzi-Biega lowland sector-Kasese; 7, Kahuzi-Biega mountain sector; 8, Itombwe Forest C; 9, Itombwe Forest A; 10, Itombwe Forest $B ; 11$, Itombwe Forest $D$; national parks designated by dot-dashed lines. 
Table 1. Population sizes for 11 subpopulations of Grauer's gorilla

\begin{tabular}{|c|c|c|c|}
\hline \multirow[b]{2}{*}{ Geographic region } & \multicolumn{2}{|c|}{ Population size } & \multirow[b]{2}{*}{ Survey method } \\
\hline & Estimate $^{*}$ & Range & \\
\hline $\begin{array}{l}\text { Kahuzi-Biega National Park } \\
\text { mountain sector }\end{array}$ & 262 & $(245-288) \dagger$ & Complete nest count \\
\hline $\begin{array}{l}\text { Kahuzi-Biega National Park } \\
\text { lowland sector-Kasese }\end{array}$ & 14,659 & $(7,410-22,203) \ddagger$ & $\begin{array}{l}\text { Line transect and forest } \\
\text { reconnaissance }\end{array}$ \\
\hline Maiko National Park north & 826 & $(444-1090) \S$ & Forest reconnaissance \\
\hline Maiko National Park south & 33 & $(18-45) \S$ & Forest reconnaissance \\
\hline Itombwe Forest A & 67 & $(32-103) \mathbb{I}$ & $\begin{array}{l}\text { Line transect and forest } \\
\text { reconnaissance }\end{array}$ \\
\hline Itombwe Forest B & 211 & $(122-301) \mathbb{I}$ & $\begin{array}{l}\text { Line transect and forest } \\
\text { reconnaissance }\end{array}$ \\
\hline Itombwe Forest $C$ & 791 & $(316-1267) \mathbb{I}$ & $\begin{array}{l}\text { Line transect and forest } \\
\text { reconnaissance }\end{array}$ \\
\hline Itombwe Forest D & 86 & $(46-125) \mathbb{I}$ & $\begin{array}{l}\text { Line transect and forest } \\
\text { reconnaissance }\end{array}$ \\
\hline Lowa River & 13 & $(0-26) \ddagger$ & Forest reconnaissance \\
\hline Mt Tshiaberimu & 16 & $(14-17)^{* *}$ & Complete nest count \\
\hline Masisi & 28 & $(0-33)+t$ & Complete nest count \\
\hline Total & 16,902 & $(8,660-25,499)$ & \\
\hline
\end{tabular}

* Total population sizes were calculated from the estimated number of weaned individuals for each population assuming a ratio of 0.33 infants per adult female (Watts, 1991) and 0.16 juveniles per weaned individual (Vedder et al., 1996).

+ Vedder et al., 1996.

$\ddagger$ Hall et al., in press.

$\S$ Hart \& Hall, 1996.

II I. Omari et al., unpublished data.

** Sarmiento and Butynski, 1997a.

t† Mwanza et al., 1988.

(1995) while one of the lowland area is included in Hall et al. (in press).

Kahuzi-Biega National Park mountain sector. The only confirmed extant population from Emlen and Schaller's (1960) Lake Kivu-Mt Kahuzi Region is found within the mountain sector of Kahuzi-Biega National Park. Until recently there has been uncertainty as to whether or not the mountain and lowland populations of Kahuzi-Biega National Park are in reproductive contact (Refisch, 1991; Yamagiwa et al., 1993; Saltonstall et al., in press); however, during a recently completed census of the mountain population the corridor was found to be effectively severed (B. Inogwabini et al., unpublished data).

Since the late 1970s several 'complete count' censuses, using methods developed in the Virunga mountains of Rwanda, Congo and Uganda (Harcourt and Groom, 1972; Groom, 1973), have been undertaken in the $600-\mathrm{sq}-\mathrm{km}$ mountain sector of Kahuzi-Biega National Park (Murnyak, 1981; Yamagiwa, 1983; Yamagiwa et al., 1993; Vedder, 1996). This is the best monitored population of the subspecies. Because it has benefited from surveillance longer than any other population, it is also the most actively protected population of Grauer's gorilla.

In 1990, before the beginning of the recent instability in the region, Yamagiwa et al. (1993) conducted a census and found the gorilla population to have increased slightly since the previous census. However, gorillas were no longer present in some of the regions noted by 
Emlen and Schaller (1960) and Schaller (1963). In May-July 1996, a census was undertaken to assess how the mountain population had fared during the previous 6 years of political turmoil. Preliminary results reported in Vedder (1996) suggest a stable population, because there is little difference between their minimum number (245) and the one reported in Yamagiwa et al. $(n=258 ; 1993)$. However, Vedder (1996) found 40 fewer nest-building individuals than Yamagiwa et al. (1993), which raises concerns about the actual status of the population. The fact that at least one individual in each of the tourist habituated groups has lost a hand to snares (J. S. Hall et al., unpublished data) underscores the precarious status of these gorillas. More recently, there have been reports that many of these gorillas were killed in the chaos after the civil war.

Kahuzi-Biega National Park lowland sectorKasese. The Utu region, described by Schaller (1963) and by Emlen and Schaller (1960) as the Walikale-Shabunda region, roughly corresponds with the area of Kahuzi-Biega National Park lowland and adjacent forest (hereafter referred to as the Kasese region) between the Lowa, Luka and Lugulu rivers. In a recent survey using line transect sampling techniques, Hall et al. (in press) found that Grauer's gorillas are no longer as widely distributed as they were during the time of Emlen and Schaller (1960; Figure 1). In contrast to Emlen and Schaller (1960), who reported areas of gorilla concentration with lower background densities throughout the Kahuzi-Biega-lowland-Kasesi area, Hall et al. (in press) found the highest densities to be within their Kahuzi-Biega lowland survey region and lower densities within their Kasese sampling zones. The authors documented anecdotal reports of heavy hunting of gorillas within the Kasese region, and attributed the combination of significantly lower group sizes and nest site densities in the Kasese survey area, coupled with a marked reduction in gorilla range, to be a result of poaching. In contrast, they concluded that the gorillas within the park's lowland sector have been relatively well protected from poaching.

\section{Maiko National Park and adjacent forest}

The Maiko National Park $\left(1^{\circ} \mathrm{N}-1^{\circ} \mathrm{S}, 27^{\circ}-\right.$ $28^{\circ} 30^{\prime} \mathrm{E}$ ) consists predominantly of lowland tropical forest (Hart and Sikubwabo, 1994). The first biological exploration of Maiko National Park was recently completed by Hart and Sikubwabo (1994). Although they were unable to estimate gorilla densities based on their data set alone, Hart and Hall (1996) reevaluated the original presence/absence data to provide an abundance estimate. Seven gorilla subpopulations were designated by Hart and Sikubwabo (1994) within and adjacent to Maiko National Park. Because Hart and Sikubwabo (1994) indicate a continuum of gorilla signs in map quadrants adjacent to and between many of their subpopulations, they are probably in reproductive contact. Thus, we initially consolidated them into three distinct populations. However, based on a recent visit, the westernmost population is believed extinct (J. Hart, pers. comm.).

We designated a northern population located within a roughly $2500-\mathrm{sq}-\mathrm{km}$ area (Figure 1). This population has not suffered from poaching and is believed to have remained relatively stable in recent years (Hart and Hall, 1996). The southern population is the Uvia population designated by Hart and Sikubwabo (1994) and has probably suffered from poaching and habitat pressure. Because both the northern and southern Maiko populations exist within a continuous forest block, much of which has not yet been surveyed, these two populations may well exchange individuals.

An additional gorilla population has recently been confirmed on the northern bank of the Lowa River (Figure 1; Hall et al., in press). Given the width and depth of the river it is doubtful that this population could be in reproductive contact with gorillas on the southern bank (Kasese region). Therefore, they are more likely to exchange individuals with the southern Maiko population. However, recent human settlement along the road as well as the likelihood of increased forest conversion will probably impede future contact between these populations. 


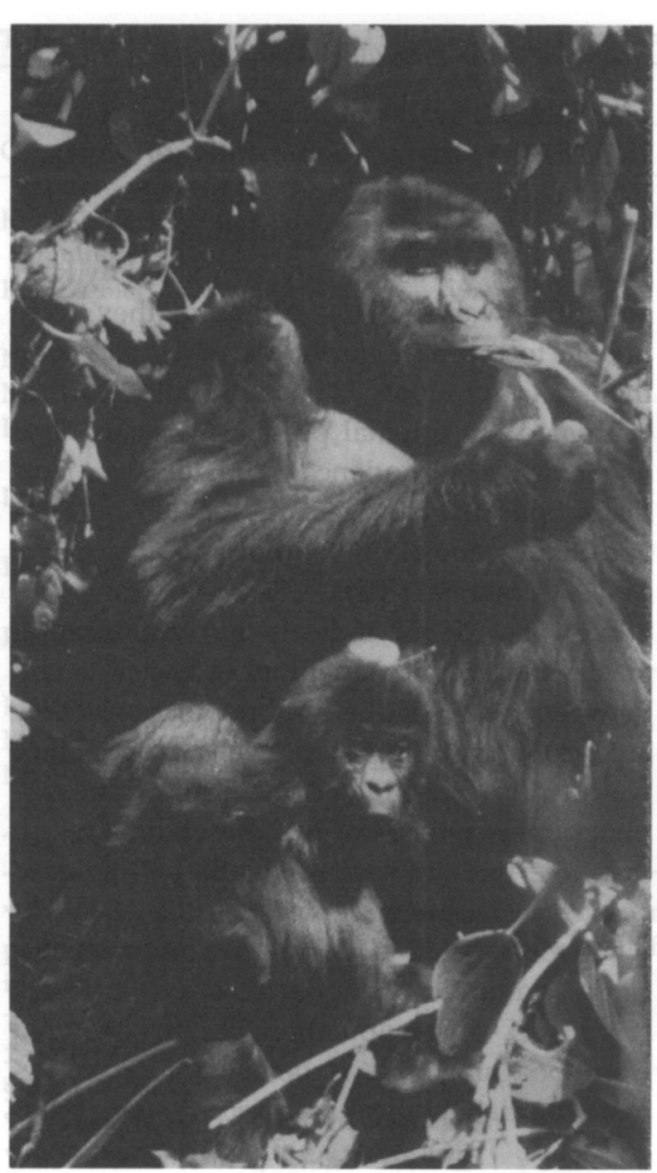

Female Graeuer's gorilla with baby from mountain sector of Kahuzi-Biega National Park (Kristin Saltonstall).

\section{Itombwe Forest}

The Itombwe Forest $\left(2^{\circ} 50^{\prime}-4^{\circ} \mathrm{S}, 28^{\circ} 15^{\prime}-29^{\circ} 4^{\prime} \mathrm{E}\right)$ consists of $11,000 \mathrm{sq} \mathrm{km}$ of montane, mountain transition and lowland tropical forest west of Lake Tanganyika (Figure 1). Until recently, only short-term assessments had been made of gorilla populations within this region (Emlen and Schaller, 1960; Wilson and Catsis, 1990; Hall and Wathaut, 1992; Sikubwabo, 1993). In 1996, I. Omari et al. (unpublished data) completed a 4-month survey using transect and forest reconnaissance methodologies. The nine subpopulations they identified can be pooled into four populations that are reproductively isolated from one another by large rivers (J. Hart, pers. comm.).
There has been extreme human pressure on the habitat of the eastern populations within this region. Hall and Wathaut (1992) and I. Omari et al. (unpublished data) documented the disappearance of gorillas recorded by Emlen and Schaller (1960) as a result of forest conversion to pasture. However, further west the forest is less accessible and therefore relatively well protected from conversion pressures. Moderate hunting pressure also has an impact on all populations within this forest (Hall and Wathaut, 1992; I. Omari et al., unpublished data).

\section{North Kivu}

Many reports suggest several small and isolated populations in the North Kivu region of Congo (Figure 1). E. Sarmiento and T. Butynski (unpublished data) reported 14 individuals on $\mathrm{Mt}$ Tshiaberimu $\left(0^{\circ} 5.8^{\prime}-0^{\circ} 9.7 \mathrm{~S}\right.$, $29^{\circ} 24.4^{\prime}-29^{\circ} 27.2^{\prime} \mathrm{E}$ ) in Virunga National Park. Mwanza et al. (1988) reported 23-25 individuals in what they refer to as the Shingisha Mabeshi gorilla reserve $\left(1^{\circ} 12^{\prime} \mathrm{S}, 28^{\circ} 51^{\prime} \mathrm{E}\right)$ in the Masisi zone. These are the best known populations in North Kivu.

Hall and Wathaut (1992) reported anecdotal accounts of other gorilla populations in the administrative zone of Masisi. In addition, $W$. M. Wathaut (pers. comm.) and J. A. Hart (unpublished data) have received reports of the presence of gorillas east of the Maiko National Park, and E. Sarmiento and T. Butynski (unpublished data) report gorilla presence at Mbohe. Thus there are potentially several small populations within this region. Until a more complete investigation can be undertaken, the number and location of different populations within North Kivu will remain unknown.

\section{Threats}

Recent studies have attempted to gauge the extent and effects of forest disappearance on both elephant and gorilla populations across central Africa (Barnes, 1990; Harcourt, 1996; Oates, 1996). In all cases, high rates of human 
population growth and intensive use of forested areas have had severe impacts on wildlife populations. The Kivu region of eastern Congo has one of the highest human population densities in central Africa. Much of the region supports densities of over 300 individuals/sq km (Mbake, 1995) and, overall, it experienced a 4 per cent rate of growth between 1950 and 1984 (Wils et al., 1976; Insititut National de la Statistique, 1984). In recent years, human population pressures on forest environments have been exacerbated by the stay of nearly one million refugees from neighbouring Rwanda and Burundi.

A series of reports has documented the threats to Grauer's gorilla posed by hunting and forest conversion (Emlen and Schaller, 1960; Schaller, 1963; Goodall, 1980; Gaeverts and Colyn, 1988; Mwanza et al., 1988; Hall and Wathaut, 1992; Hart and Sikubwabo, 1994; Hart and Hall, 1996). Today the most significant threat is the burgeoning human population's increasing need for land. Outside protected areas, people clear forest and eliminate gorilla populations with little regard for their protected status (Goodall, 1980; Hall and Wathaut, 1992; Hall et al., in press). Yet forest conversion is not the only threat facing gorillas. In areas of low human population density, gorillas are often considered pests and are killed in retaliation for crop raiding and for meat (Emlen and Schaller, 1960; Schaller, 1963; Goodall, 1980; Hall and Wathaut, 1992; Hart and Hall, 1996; Hall et al., in press).

While some gorillas are hunted within protected areas, the presence of the National Park Service has served as a significant deterrent (Butynski and Sarmiento, 1995; Hall et al., in press). Nevertheless, setting wire snares to capture medium- and small-bodied terrestrial mammals has proved a difficult problem to combat. Even the best protected Grauer's gorillas, those habituated for tourists in the Kahuzi-Biega mountain sector, are threatened by wire snares. Killing of adult gorillas as a result of the capture of infants for illegal trade in international markets has also increased in recent years and probably occurs in national parks as well as unprotected forests.

\section{Discussion}

The population of the Kahuzi-Biega National Park lowland sector and adjacent Kasese region represents 86 per cent of the overall G. $g$. graueri population. In the recent past these two gorilla subpopulations have been subject to different human pressures because of the non-protected status of the Kasese region. Heavy hunting in the past has probably been the cause of population decline in the region (Hall et al., in press). However, today this large continuous population forms the core of Grauer's gorilla populations as a whole and should remain a focus of conservation efforts for the subspecies.

One additional threat to the gorillas of the Kahuzi-Biega National Park lowland sector stems from the recent delineation of the park boundaries in the Itebero area. Prior to the delineation, the Luka River was considered as the park boundary. A substantial area that previously had been treated as park has now been zoned outside the park. This area was found by Hall et al. (in press) to have the second highest densities of gorillas within the population. Because gorillas outside the park have clearly not fared as well as those within the park, efforts must be made to ensure that the gorillas are not adversely affected by the increased human use.

The gorillas of the Itombwe Forest region have been subject to varying degrees of human pressures but have persisted throughout the region (I. Omari et al., unpublished data). These populations may also represent an important component of Grauer's gorilla genetic diversity because of their geographic isolation from other populations (Figure 1). Recent initiatives to work with local people in the area to protect gorillas (Schilter and Doumenge, 1993) were encouraging but have ceased with the political instability in the region. The rapidly increasing human population coupled with this instability could foreshadow the doom of otherwise viable populations of gorillas. Therefore it is imperative that the Itombwe gorillas become a more visible focus of gorilla conservation.

The gorilla population inhabiting the north- 
ern portion of Maiko National Park is apparently little threatened and its conservation prospects look very good. Nevertheless, given projected human immigration and deforestation trends (Barnes, 1990), these gorillas could soon experience threats similar to those of the southern Maiko National Park and the Kahuzi-Biega National Park lowland sectorKasese region. The park is understaffed, and training and infrastructure are poor (Hart and Sikubwabo, 1994; Hart and Hall, 1996). Efforts here should be proactive so that staff are able to deal with the complexities of human conflict.

The fate of the remaining three Grauer's gorilla populations described here is more problematic. The environmental legacy of increased land conversion and fuel-wood shortages left by the recent stay of approximately one million Rwandan refugees in the region is yet to be seen. Regardless of the refugees, these gorilla populations are surrounded by a dense human population that requires land and forest resources (e.g. fuel wood, building materials). Even if the Park Service's enforcement capacity is buttressed in the $\mathrm{Mt}$ Tshiaberimu area of Virunga National Park, serious questions remain about the population's long-term survival because of intense land use, isolation and its small size. Similarly, without extraordinary efforts within a tremendously volatile region, we predict that the Masisi population may also disappear in the very near future. In fact, unconfirmed reports indicate that this population has recently been eliminated. The population near the Lowa River is also at risk because of its small size and isolation.

The successful conservation of Grauer's gorilla populations will necessitate a multi-disciplinary approach. The combined results from recent surveys indicate that 67 per cent of the extant population of Grauer's gorillas is found within national park boundaries. The apparent success of the Park Service in maintaining these populations suggests that they serve as a core for conservation of the subspecies.

Although 17 per cent of forested land in eastern Congo is currently within protected areas (Hart and Hall, 1996), creative alternatives to protect other forested lands must be explored. Due to extensive public opposition, designation of additional parks and expansion of current protected areas is not feasible. However, community-based efforts to conserve forest resources through education and sustainable uses are possible and therefore can complement conservation efforts within the parks. Efforts are also needed to control the conditions that have forced humans to compete with gorillas and other species for land. With a growing human population, demand for land and other natural resources will continue to increase.

While the total number of Grauer's gorillas is a positive indicator of long-term survival of the subspecies, we recognize that the negative effects of habitat clearance and fragmentation, as well as hunting pressures, will increase for all Grauer's gorilla populations. Thus, the optimism offered by our population size estimates should not be accompanied by complacency. Unconfirmed reports of gorillas having been killed within the mountain sector of Kahuzi-Biega National Park and of rebel activity within the lowlands highlights the urgent need to buttress conservation efforts for these gorillas. This analysis suggests that a unique opportunity remains to ensure the conservation of the subspecies well into the next millennium. However, without significant and sustained conservation efforts, the opportunity will be lost.

\section{Acknowledgments}

The Kahuzi-Biega National Park (KBNP) lowland sector and adjacent forest, Maiko National Park (MNP), Itombwe Forest surveys and the KBNP mountain sector census were financed by the Wildlife Conservation Society (WCS) in collaboration with the Zairean National Park Service. The Walt Disney Corporation provided additional support for the survey of the Kasese region and the census of the mountain sector of KBNP, while Bergorilla und Regenwald Direkthilfe provided additional support for the KBNP, MNP and Itombwe Forest surveys. The Deutsche Gesellschaft für Zusammenarbeit (GTZ) provided logistical assistance for the work in KBNP, and Zoo Atlanta collaborated in the Itombwe Forest Survey. The project could not have been undertaken without the sup port of A. Vedder and Mankoto ma Mbaelele. We 
would like to thank all those who participated on different aspects of the surveys summarized herein. D. Skelly, T. Butynski and an anonymous referee reviewed the manuscript. G. Schaller generously shared information from previous surveys. Finally, we owe an enormous debt of gratitude to our guides, porters and field staff without whom this work could not have been carried out.

\section{References}

Barnes, R.F.W. 1990. Deforestation trends in tropical Africa. African Journal of Ecology, 28, 161-173.

Butynski, T. and Sarmiento, E. 1995. Gorilla census on Mt Tshiaberimu: preliminary report. Gorilla Journal, 1, 11.

Carroll, R.W. 1988. Relative density, range extension, and conservation potential of lowland gorilla (Gorilla gorilla gorilla) in the Dzanga-Sangha region of southwestern Central African Republic. Mammalia, 52, 309-323.

Emlen, J.T. and Schaller, G.B. 1960. Distribution and status of the mountain gorilla (Gorilla gorilla beringei) - 1959. Zoologica, 45, 41-52.

Fay, J.M. 1989. Partial completion of a census of the lowland gorilla (Gorilla g. gorilla (Savage and Wayman)) in southwestern Central African Republic. Mammalia, 53, 203-215.

Fay, J.M., and Agnagna, M. 1992. Census of gorillas in northern Republic of Congo. American Journal of Primatology, 27, 275-284.

Gaeverts, H. and Colyn, M. 1986. Analyse craniométrique des populations de Gorilla gorilla graueri (Primates) de la rivière Lowa et comparison avec d'autres populations du bloc forestier centre-africaine. Annales de la Faculté des Sciences, Université de Kisangani, 27-30.

Goodall, A.G. 1980. Pilot survey for conservation management of eastern gorillas in Zaire. Final Report. IUCN/WWF Project 1731.

Groom, A.F. 1973. Squeezing out the mountain gorilla. Oryx, 12, 207-215.

Hall, J. and Wathaut, W.M. 1992. A preliminary survey of the eastern lowland gorilla. Wildlife Conservation Society, New York.

Hall, J.S., White, L.J.T., Inogwabini, B.I. et al. In press. A survey of Grauer's gorillas (Gorilla gorilla graueri) and chimpanzees (Pan troglodytes schweinfurthi) in the Kahuzi-Biega National Park lowland sector and adjacent forest in eastern Zaire. International Journal of Primatology.

Harcourt, A.H. 1996. Is the gorilla a threatened species? How should we judge? Biological Conservation, 75, 165-176.

Harcourt, A.H. and Groom, A.F.G. 1972. Gorilla census. Oryx, 28, 59-70.
Harcourt, A.H., Fossey, D. and Sabater-Pi, J. 1981. Demography of Gorilla gorilla. Journal of Zoological Society of London, 195, 215-233.

Hart, J.A. and Hall, J.S. 1996. Status of eastern Zaire's forest parks and reserves. Conservation Biology, 10, 316-324.

Hart, J.A. and Sikubwabo, C. 1994. Exploration of the Maiko National Park of Zaire 1989-1992: History, environment and the distribution and status of large mammals. Wildlife Conservation Society, New York.

Institut National de la Statistique. 1984. Recensement scientifique de la population 1984: projections demographiques Zaire et regions, 1984-2000. Ministere du Plan et Amenagement du Territoire, Kinshasa.

Mbake, S. 1995. The Kahuzi-Biega National Park and the IZCN/GTZ project. Gorilla Journal, 1, 12-13.

Murnyak, D.F. 1981. Censusing the gorillas in Kahuzi-Biega National Park. Biological Conservation, 21, 163-176.

Mwanza, N., Maruhashi, T., Yumoto, T. and Yamagiwa, J. 1988. Conservation of eastern lowland gorillas in the Masisi region, Zaire. Primate Conservation, 9, 111-114.

Oates, J. 1996. Habitat alteration, hunting and the conservation of folivorous primates in Africa. Australian Journal of Ecology, 21, 1-9.

Refisch, J. 1991. Presence des grands mammiferes dans le Parc National de Kahuzi-Biega et l'influence humaine sur les populations des animaux. Rapport dans le cadre du Projet IZCN/GTZ - Conservation de la Nature Intégrée, l'Est Zaire.

Saltonstall, K., Amato, G. and Powell, J. In press. Mitochondrial DNA variability in Grauer's gorillas of Kahuzi-Biega National Park. Journal of Heredity.

Schaller, G.B. 1963. The Mountain Gorilla, Ecology and Behavior. The University of Chicago Press, Chicago.

Schilter, C. and Doumenge, C. 1993. Programme Itombwe: rapport de mission, 19 juillet au 19 aout 1993. IZCN/UICN, Zaire.

Sikubwabo, C.K. 1993. Rapport de mission enquete faune-chase: programme Itombwe. IZCN/IUCN, Bukavu.

Steinhauer-Burkhart, B., Muhlenberg, M. and Slowik, J. 1995. Kahuzi-Biega National Park. IZCN/GTZ Project, Zaire.

Tutin, C. and Fernandez, M. 1984. Nationwide census of gorilla (Gorilla g. gorilla) and chimpanzee (Pan t. troglodytes) populations in Gabon. American Journal of Primatology, 6, 313-336.

Vedder, A. 1996. Projet inventaire des gorilles et d'autres grands mammiferes de l'est du Zaire: secteur original du Parc National de Kahuzi-Biega. Institut Zairois pour la Conservation de la Nature/ 
Wildlife Conservation Society.

Watts, D.P. 1991. Mountain gorilla reproduction and sexual behavior. American journal of Primatology, 24, 211-225.

Weber, A.W. and Vedder, A. 1983. Population dynamics of the Virunga gorillas 1959-1978. Biological Conservation, 26, 341-366.

Wils, W., Carael, M. and Tondeur, G. 1976. Le Kivu montagneux: surpopulation - sous nutrition - erosion du sol. Etude prospective par simulations mathematiques. CEMUBAC/IRS, Zaire.

Wilson, J.R. and Catsis, M. 1990. A preliminary survey of the forests of the 'Itombwe' mountains and the Kahuzi-Biega National Park extension, east Zaire, July-September 1989. Project Report for WWF Project 3902.

Yamagiwa, J. 1983. Diachronic changes in two eastern lowland gorilla groups (Gorilla gorilla graueri) in the Mt Kahuzi region, Zaire. Primates, 24, 174-183.

Yamagiwa, J., Mwanza, N., Spangenberg et al. 1993. A census of the eastern lowland gorillas Gorilla gorilla graueri in Kahuzi-Biega National Park with reference to mountain gorillas G. g. beringei in the
Virunga Region, Zaire. Biological Conservation, 64 83-89.

Jefferson S. Hall, Wildlife Conservation Society, International Conservation, 185th Street and Southern Blvd., Bronx, NY 10460, USA. Address for correspondence: School of Forestry and Environmental Studies, Yale University, 360 Prospect Street, New Haven, CT 06511, USA; Email: jefferson.hall@yale.edu

Kristin Saltonstall, Department of Ecology and Evolutionary Biology, Yale University, New Haven, CT 06520, USA.

Bila-Isia Inogwabini, Wildlife Conservation Society, International Conservation, 185th Street and Southern Blvd., Bronx, NY 10460, USA.

Ilambu Omari, Institut Congolais pour la Conservation de la Nature, Kinshasa, Democratic Republic of Congo.

Received 24 July 1997

Accepted 5 January 1998 